just place in the world unless they preserve their cultural heritage which is the most distinctive feature of their individuality', the delegates urged the adoption by the General Conference, at its next session, of 'an emergency programme designed to hasten the process of preservation and development of African cultures'. They considered 'that a national cultural policy in Africa necessitates the conduct, at the same time, of general literacy campaigns making use of powerful means to place the essential results of African research at the disposal of the masses' and recommended that all African States 'give a considerable place in their school and college educational curricula to African culture'.

\title{
International Congress of African History
}

THE Society of African Culture (Présence Africaine) is organizing an International Congress of African History to take place in Dar-es-Salaam, Tanganyika, from I to 7 September I964. The main themes of the Congress are to be the principles and methods of African historiography, African history and associated sciences, and the organization and practical problems of research work in African history. Myths, sources, chronological divisions and territorial structures, and the diffusion of African history in schools will be among the aspects treated under the first heading, while African history will be related to geography, archaeology, linguistics, anthropology, and sociology under the second. Organization and practical problems will include a critical inventory of present-day publications, local archives and study centres, discussion of practical methods for recording oral traditions, inter-African and international co-operation, and a project for a basic school textbook. Further information about the Congress may be obtained from the Society of African Culture (Présence Africaine), 42 rue Descartes, Paris $5^{\mathrm{e}}$.

\section{African Museums}

Museum, the quarterly review published by Unesco, has devoted a recent number (vol. xvi, no. 3, 1963 ) to African museums. The following articles are included:

The Museums of Nigeria

The Uganda Museum, Kampala: the programme and the organization

The Uganda Museum, Kampala: the public

The National Museum of Tanganyika, Dar-es-Salaam

The Rhodes-Livingstone Museum, Livingstone

The National Gallery of Salisbury and its workshop-school

The Coryndon Museum, Nairobi, and the role of natural history museums in Tropical Africa

The National Museum of the Republic of Niger, Niamey

\section{Bernard Fagg}

Merrick Posnansky

Valerie Vowles

Stanley E. West

Gervase C. R. Clay

Frank McEwen

R. H. Carcasson

Pablo Toucet

Museum may be obtained from H.M. Stationery Office, P.O. Box. 569, London, S.E. I.

\section{Unesco Directory of Specialists in African Studies}

A DrRECTORY entitled Social Scientists Specializing in African Studies has been prepared by the Secretariat of Unesco. Its principal aim has been to achieve as large a coverage as possible and it brings together data on social scientists specializing in African studies from the whole African continent as well as from countries all over the world. Priority has been given to specialists in the central disciplines in the social sciences, such as economics, social and cultural anthropology, sociology, psychology, political science, and law, and also to more specialized fields such as rural and industrial sociology, labour relations, \&c. A certain number of specialists in archaeology, history, folklore, musicology, and linguistics have 